\title{
RUTHENIUM VOLATILITY FROM THE VITRIFICATION OF MELTER FEEDS PREPARED USING THE NITRIC ACID FLOWSHEET (U)
}

by N.D. Hutson

WSRC-T'R--92-490

Westinghouse Savannah River Company

Savannah River Site

DE93 006871

Aiken, South Carolina 29808

Other Authors:

\section{POCIVED \\ FEB - 51993 \\ OSTI}

This paper was prepared in connection with work done under Contract No. DE-AC09-89SR18035 with the U.S. Department of Energy. By acceptance of this paper, the ' blisher and/or recipient acknowledges the U.S. Government's right to retain a nonexclusive, royalty-free icense in and to any copyright covering this paper, along with ihe right to reproduce and to authorize others to reproduce ai!' or part of the copyrighted paper. 


\section{DISCLAIMER}

This report was prepared as an account of work sponsored by an agency of the United States Government. Neither the United States Government nor any agency thereof, nor any of their employees, makes any warranty, express or implied, or assumes any legal liability or responsibility for the accuracy, completeness, or usefulness of any information, apparatus, product, or process disclosed, or represents that its use would not infringe privately owned rights. Reference herein to any specific commercial product, process, or service by trade name, trademark, manufacturer, or otherwise does not necessarily constitute or imply its endorsement, recommendation, or favoring by the United States Government or any agency thereof. The views and opinions of authors expressed herein do not necessarily state or reflect those of the United States Government or any agency thereof.

This report has been reproduced directly from the best available copy.

Available to DOE and DOE contractors from the Office of Scientific and Technical Information, P. O. Box 62, Oak Ridge, TN 37831; prices available from (615) $576-8401$.

Available to the public from the National Technical Information Service, U. S. Department of Commerce, 5285 Port Royal Rd., Springfield, VA 22161. 
Keywords: DWPF, IDMS, Ruthenium, Nitric Acid Flowsheet, Late Wash

\section{Retention: Permanent}

CC: L. M. Papouchado, 773-A

L. F. Landon, 704-T

C. T. Randall, 704-T

J. T. Carter, 704-1T

M. J. Plodinec, 773-A

N. E. Bibler, 773-A

D. F. Bickford, 773-A

J. R. Zamecnik, 704-1T

SRTC Records (4)

October 22,1992

TO: $\quad$ E. W. Holtzscheiter, 773-A

FROM: N. D. Hutson, 704-1T

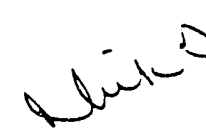

Ruthenium volatility from the vitrification of Melter Feeds prepared Osing the Nitric Acid Flowsheet (U)

\section{Introduction}

The present DWPF flowsheet calls for the chemical treatment of waste sludge with 90 wto formic acid prior to the addition of the Precipitate Hydrolysis Aqueous (PHA) product. An alternative processing methodology, denoted the "Nitric Acid Flowsheet", has been proposed. In the application of this flowsheet: nitric acid would be used to neutralize sludge base components (hydroxides and carbonates) prior to the addition of late wash PHA. The late wash PHA will contain sufficient quantities of formic acid to adequately complete necessary reduction-oxidation (REDOX) reactions.

The use of this flowsheet may result in a change in the nominal concentrations of two of the major REDOX reaction participants: formate $\left(\mathrm{HCOO}^{-}\right)$and nitrate $\left(\mathrm{NO}_{3}{ }^{-}\right)$.

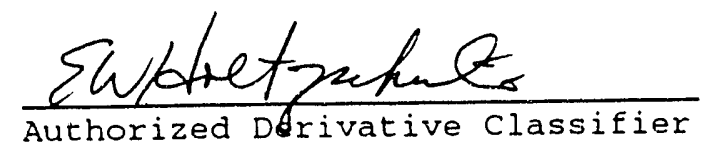


An imbalance in REDOX agents in the melter can result in overly reducing melts which favor the formation and accumulation of metals and metallic sulfides (including selenides and tellurides). Conversely, if the REDOX potential of the melt is imbalanced to the point of being overly oxidizing, there is an increased potential for melter foaming. Further, there may be an increased amount of volatilized ${ }^{106} \mathrm{Ru}$ since nitrates act. as oxidizing agents in glass melting and therefore stabilize the highly oxidized, gaseous $\mathrm{RuO}_{4}$.

\section{Background}

Control of radioactive ruthenium was an early process concern because of expected difficulty in scrubbing out the volatile ruthenium tetroxide $\left(\mathrm{RuO}_{4}\right)^{1}$. In 1983, soper ${ }^{2}$ verified thermodynamic calculations which indicated that this species is unstable in the offgas system, decomposing to the scrubbable particulate $\mathrm{RuO}_{2}$. Based the kinetics of the decomposition of $\mathrm{RuO}_{4}$, Soper estimated that particulate $\mathrm{RuO}_{2}$ is formed in 0.04 seconds or less in the cool offgas line exiting the melter. This decomposition is catalyzed by different kinds of steels and by $\mathrm{RuO}_{2}$ itself and does not depend on the amount of ruthenium in the offgas system.

Experimental verification of this result was provided by Klein, et.al.3 This work showed that, even for European waste slurries which are air sparged and very high in nitrates, ruthenium is transported from the melter as particulate $\mathrm{RuO}_{2}$. (Note that the study also revealed that the volatilization of Ru was approximately 5 times higher in waste calcination than in direct slurry fed vitrification.) In melting studies at the Savannah River Laboratory, using actual waste, no ruthenium was found past the scrubber section $4,5,6$ even in non-reducing atmospheres.

\section{Ruthenium Volatility in the IDMS Melter}

The extent of Ru volatility from the IDMS melter is judged in two ways: (1) analysis of offgas header deposits, and (2) analysis of offgas condensate. Since any gaseous $\mathrm{RuO}_{4}$ will decompose almost immediately upon entering the offgas exit line, the $\mathrm{RuO}_{2}$ particulate is likely to deposit on the piping with other volatile and semi-volatile compounds (alkali halides, borates, sulfates) and entrained matter (dried feed, spinels, and frit). And, any $\mathrm{RuO}_{2}$ particulate entering the quencher would be scrubbed to the condensate.

The offgas header deposits have been analyzed from IDMS runs of various conditions. Samples were taken after using the formic acid flowsheet (for both SRS and Hanford wastes) and after using the nitric acid flowsheet. These samples were analyzed by Scanning Electron Microscopy / Energy Dispersive 
$X$-Ray (SEM/EDX) and by Inductively Coupled Plasma - Atomic Emission Spectroscopy (ICP-AES). The results are sumnarized in the following table:

\begin{tabular}{|c|c|c|c|}
\hline Run Type & $N / F^{*}$ & Ru (wt\%) & Sample Description \\
\hline $\begin{array}{l}\text { Formic Flowsheet } \\
\text { (horiz section) }\end{array}$ & $<1.0$ & $<0.9 \%$ & $\begin{array}{l}\text { Not much Ru found, } \\
\text { found as oxide but } \\
\text { mostly associated } \\
\text { with entrained spinels. }\end{array}$ \\
\hline $\begin{array}{l}\text { HWVP1 }\left(\text { NCAW) }{ }^{7}\right. \\
\text { (horiz section) }\end{array}$ & 1.5 & $5.2 \%$ & $\begin{array}{l}\text { Ru present as oxide, } \\
\text { mixed with Rh, Te, and } \\
\text { Cd, and associated with } \\
\text { spinels. }\end{array}$ \\
\hline $\begin{array}{l}\text { HWVP2 } \\
\text { (horiz } \\
\text { (hection) }\end{array}$ & 1.3 & $2.9 \%$ & Same as HWVP1 \\
\hline $\begin{array}{l}\text { Nitric Flowsheet } \\
\text { (horiz section) }\end{array}$ & $8-16$ & $3.9 \%$ & NA (no SEM/EDX yet) \\
\hline $\begin{array}{l}\text { Nitric Flowsheet } \\
\text { (quencher) }\end{array}$ & $8-16$ & $1.5 \%$ & NA (no SEM/EDX yet) \\
\hline $\begin{aligned} * N / F & =\text { Nitrate }- \text { to }-F \\
N A & =\text { Not Availabl }\end{aligned}$ & nate mo & - ratio & \\
\hline
\end{tabular}

Analysis of IDMS offgas condensates have provided limited information on ruthenium volatility since the condensate is normally analyzed by filtering the very small fraction of solids from the liquid before injecting directly into the ICP-AES instrument. $\mathrm{RuO}_{2}$ is quite insoluble and would mostly be removed from the condensate sample. Analysis of these insoluble solids revealed that they are mostly spinels, $\mathrm{Fe}_{2} \mathrm{O}_{3}$, $\mathrm{AgCl}, \mathrm{AgI}$, and ruthenium. The ruthenium is associated mostly with the spinels but also present as $\mathrm{RuO}_{2}$ crystals.

To date, no particulate sampling (specifically for $R u$ compounds) has been conducted in the melter system.

\section{DWPF Design Basis}

The material balance tables for the DWPF 8 predict that approximately $1 \%$ of the Ru entering the melter will exit as semi-volatile $\mathrm{RuO}_{2}$ (particulate aerosol). This assumes that the Ru will first be volatilized to $\mathrm{RuO}_{4}$ and almost immediately decomposed to $\mathrm{RuO}_{2}$ in the offgas exit line. The following DF's (Decontamination Factors) have been assumed for the removal of the $\mathrm{RuO}_{2}$ aerosol: 


$\begin{array}{lr}\text { Offqas Equipment } & \underline{D F^{\star}} \\ \text { Melter } & 100 \\ \text { Quencher } & 1 \\ \text { Scrubbers (2) } & 14 \\ \text { OG Condenser } & 1 \\ \text { HEME (stage 1) } & 1 \\ \text { HEPA (stage 2) } & 200 \\ \text { HEPA (s) Filter } & 10 \\ \text { Sand Filty of } \mathrm{RuO}_{2} \text { in)/(quantity of } \mathrm{RuO}_{2} \text { out) } & 200 \\ \text { * DF = (quantity }\end{array}$

\section{Sonclusions}

Melter feeds which are high in nitrates can increase the volatility of ${ }^{106} \mathrm{Ru}$ due to the formation of the highly oxidized, gaseous $\mathrm{RuO}_{4}$ during vitrification. However, $\mathrm{RuO}_{4}$ is very unstable especially at the cooler temperatures of the offgas exit line. Thermodynamic and kinetics calculations have shown that any $\mathrm{RuO}_{4}$ exiting the melter will rapidly decompose to scrubbable particulate $\mathrm{RuO}_{2}$. Analysis of IDMS offgas deposit samples suggest that with nitrate-to-formate molar ratios $>1.0$ there is an increased amount of $\mathrm{Ru}$ in the deposited material (which implies that more Ru is volatilized and/or entrained).

The maximum amount of $\mathrm{Ru}$ found in the offgas deposits represents $\approx 1 \%$ of the Ru fed to the melter (which corresponds to the assumption made for the DWPF material balances). However, this Ru is mostly found associated with spinel crystals and not as condensed $\mathrm{RuO}_{2}$.

Since no Ru-specific particulate sampling has been conducted in the melter system, it is not possible to know absolutely the amount of $\mathrm{Ru}$ which exits the melter as condensed $\mathrm{RuO}_{2}$. This is further complicated by the fact that a large portion of the Ru entering the melter settles to and accumulates on the melter floor (so the amount in the offgas cannot merely be assumed to be the difference between that in the melter feed and that in the glass product).

However, all evidence suggests that even if there is an increased amount of $\mathrm{Ru}$ exiting the melter with the use of the nitric acid flowsheet, there should not be an increase in the predicted DWPF release rates. The DF's for most of the offgas equipment have been conservatively set. For example, the DF for the 2-stage HEPA is assumed to be 2000 while practical experience has shown this to be as high as $1 \times 10^{5}$. With this conservatism and the fact that the N/F for the Nitric Acid/Late wash Flowsheet will change only slightly from the reference (Formic Acid) flowsheet, there are no anticipated increases in ${ }^{106} \mathrm{Ru}$ emissions from the DWPF. 


\section{References}

1. D.F. Bickford, R.B. Diemer, and D.C. Iverson, "Redox Control of Electric Melters with Complex Feed Compositions II. Preliminary Limits for Radioactive Waste Melters", Journal of Non-Crystalline Solids, 84 (1986) 285-291.

2. P. D. Soper, "Elimination of Ruthenium Absorption Bed", USDOE Report DPST-82-0614, Savannah River Laboratory, Aiken, SC 29808 (1982).

3. M. Klein, C. Weyers, and W. Goosens, "Volatilization and Trapping of Ruthenium in High Temperature processes", Proceedings of the $17 t h$ DOE Nuclear Air Cleaning Conference.

4. G. B. Woolsey, and E. L. Wilhite, "Characterization of Off-Gases From a Small-Scale, Joule-Heated Ceramic Melter For Nuclear Waste Vitrification," USDOE Report DP-MS-7992, presented at the 82 nd Annual Meeting of the American Ceramic Society, April 27-30, 1980.

5. G. B. Woolsey, "Off-Gas Characterization From The Vitrification of Tank 15 Waste," USDOE Report DPST-81666, Savannah River Laboratory, Aiken, SC 29808 (1981).

6. M. J. Plodinec, P. D. Soper, N. E. Bibler, and J. L. Kessler, "SRP Radioactive Glass Studies: Small-scale Process Development and Product Performance, " USDOE Report DP-MS-82-26, Savannah River Laboratory, Aiken, SC 29808 (1982).

7. N. D. Hutson, "Integrated DWPF Melter System Campaign Report: Hanford Waste Vitrification Plant (HWVP) Process Demonstration", USDOE Report WSRC-TR-92-0403, Savannah River Technology Center, Aiken, SC 29808 (1992).

8. A. S. Choi and J. R. Fowler, "Material Balance Tables For The DWPF Basic Data Report (DPSP-80-1033) Revision 138 Appendix G, Table 19-1", USDOE Report WSRC-TR-90-0093, Savannah River Technology Center, Aiken, SC 29808 (1990). 

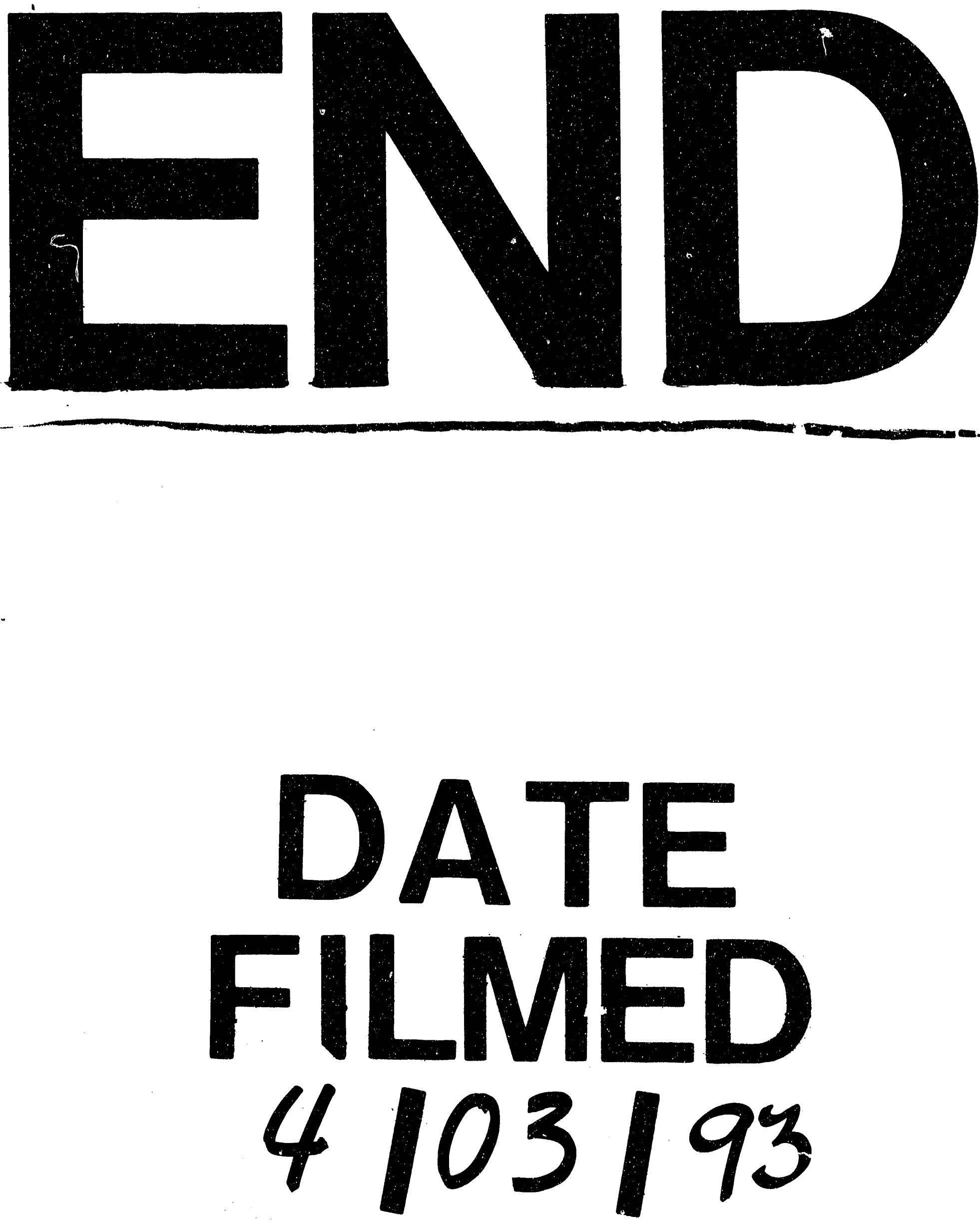
